energy. A mixture of chlorine and hydrogen gases diluted with air or oxygen combines slowly in light. Without air the mix. ture is exploded (as Tyndall has shown in well-known experiments) by exposure to white light, the chemical rays being most efficient. M. Dufour has examined the behaviour of this mixture as to its power of yielding radiophonic and photophonic sounds when illuminated by intermittent beams of different kinds, as in the researches of Graham Bell and Tainter. He finds that the loudest sounds occur when violet and ultra-violet rays are employed, no sound whatever being produced by red rays.

WE notice in the last number of the Fournal of the Russian Chemical and Physical Society (vol. xiii.), a paper, by $M$. Kraevitch, on the limit of rarefaction which might be obtained by means of mercury.pumps. M. Kraevitch affirms that in such a pump the tube will always remain filled with vapours of mercury, the elasticity of which, at ordinary temperatures, is no less than 0.02 millimetre; the use of desiccative substances cannot make these vapours disappear, as new vapours are immediately formed agaill. He contests therefore the idea that Mr. Crookes might have obtained in his experiments so low a pressure as 0.00004 metre ; and observes that M'Leod's gauge can measure the elasticity of a permanent gas (admitting that the law of Mariotte were true at such low pressures), but that it does not give the elasticity of the vapours of mercury. After a sketch of different air-pumps, he recommends that of Prof. Mendeleeff, with some modifications of his own, the most important of which is intended to eliminate the inconvenience which Mendeleeff's pump has in common with that of Sprengel, namely, the adhesion of an airfilm to the glass-tube at low pressures. The rarefaction of the air, he says, can be carried in this pump so far as to reduce the elasticity of the permanent gas to $0^{\prime} 0002$ millimetre, the pressure of the vapours of mercury always remaining, however, no less than 0.02 millimetre at the usual temperature of our rooms. In a few hours the rarefaction may be produced as to show the fluorescence of glass at the negative pole and the other phenomena described by Mr. Crookes, and even to stop the transmission of electricity.

\section{THE PRIZES OF THE PARIS ACADEMY}

THE following is, in brief, a list of the prizes offered in connection with specified subjects in $\mathbf{1} 882$ and following years:-In 1882: Grand prize of the Mathematical Sciences (medal worth $3000 \mathrm{fr}$.): Theory of the decomposition of whole numbers in a sum of five squares. Extraordinary prize of $6000 \mathrm{fr}$. : Progress increasing the efficiency of the naval forces. Plumey prize (medal, $2500 \mathrm{fr}$.): Improvement of steam-engines, or of steam-navigation otherwise. Damoiseau prize (medal, I0,000 fr.): Revision of the theory of Jupiter's satellites. Grand prize of the Mathematical Sciences (medal, $3000 \mathrm{fr}$.) : Experimental and theoretical study of the elasticity of one or several crystalline snbstances. Bordin prize (medal, $3000 \mathrm{fr}$.) : Origin of atmospheric electricity and cause of phenomena in thunderclouds. Desmazières prize (medal, I600 fr.): Best work in cryptogamy. Vaillant prize (medal, $4000 \mathrm{fr}$.): Inoculation as a prophylactic in contagious diseases of domestic animals. Grand prize of the Physical Sciences (medal, $3000 \mathrm{fr}$.) : Distribution of marine animals on the French coast. Du Gama Machado prize (medal, I $200 \mathrm{fr}$.) : On coloured parts of the tegumentary system of animals, or on the fecundating matter of animated beings. Breant prize (interest on 100,000 fr.) : Cure of Asiatic cholera. Godard prize (medal, Iooo fr.) : Anatomy, physiology, and pathology of the genito-urinary organs. Lalle. mand prize (I800 fr.): Work on the nervous system. Gay prize (2500 fr.): Marine lacustrine and terrestrial deposits on the French coasts in the present period, and especially since the Roman epoch. In addition, there are the Montyon prize in Mechanics, the Lalande and Valz prizes in Astronomy, and several others. Then in 1883 : Fourneyron prize $\left(500 \mathrm{fr}_{0}\right)$ : Different modes of transmission of force to a distance. Grand prize of the physical sciences (medal, $3000 \mathrm{fr}$.): Geological description of a region of France or Algeria. De la Fons Melicoque prize (300 fr.) : Botanical work on the North of France. Bordin prize $(3000$ fr.) : Influence of medium on the structure of vegetating organs; variations of terrestrial plants grown in water, and of aquatic plants in air; explain by direct experiments the special forms of some species of maritime flora. Bordin prize (medal, $3000 \mathrm{fr}$.) : Palæontology of France or Algeria. Grand prize of the physical sciences (medal, $3000 \mathrm{fr}$.): Histological development of insects during their metamorphoses. Alphonse Penaud prize (3000 fr.) : Aërial locomotion. In I884: Sener prize (7500 fr.): On genera embryology applied as much as possible to physiology and medi cine. In 1885 : Dusgate prize (2500 fr. ): Diagnostic signs of death and means of preventing precipitate inhumation. In I 886 the Jean Renaud prize will be awarded for the most meritorious work during five years.

\section{SYMBIOSIS OF ALGAE AND ANIMALS}

$A$ CORRESPONDENT sends us the following as an epitome of $\mathrm{K}$. Brandt's experiments on the green bodies found in the bodies of Hydra, Spongilla, Stentor, \&c. :-

When the green bodies are removed from these organisms by crushing, they are found not to be entirely and uniformly green like the chlorophyll-bodies of plants; in addition to the green substance they consist also of colourless protoplasm. Treatment with hæmatoxylin always reveals a definite cell-nucleus; and the same is the case if first killed by $0^{\circ} 2$ per cent. chromic acid or I per cent. superosmic acid, then freed from chlorophyll by alcohol, and finally treated with solution of hæmatoxylin. These green bodies do not therefore correspond to the chlorophyllbodies of algæ, but are themselves independent organisms, unicellular algæ. To those found in the animals named above the author gives the generic name Zoochlorella, to those which occur in the Radiolaria, Actiniz, \&c., the name Zooxanthella. Experiment proved that they are capable of carrying on an independent existence after removal from the animal in which they are found, and are able to produce starch-grains. They can also enter into the bodies of other animals which feed on those that contain them. The physiological function of these algæ was investigated in the case of those which form the well-known "yellow cells" of the Radiolaria. These were found to be of service in supplying food to the host, which thrives best in perfectly pure filtered water. So long as the animals contain few or no green or yellow algæ, they are nourished, like true animals, by the absorption of solid organic substances; but as soon as they conrain a sufficient quantity of these algæ, they are nourished, like true plants, by assimilation of inorganic substances. In the latter case the alger which live in the animals perform altogether the function of the chlorophyll-bodies of plants. Finally the author compares the mode of life of these Phytozod (as he terms the animals which subsist on the algæ contained within them) with that of Lichens. With the Phytozoa there is, however, this remarkable peculiarity, that morphologically it is the alga, physiologically the animal which is the parasite.

\section{NOTES ABOUT SNAKES}

$A$ SERPENT'S first instinctive impulse of self-preservation, like that of every other animal, lies in escape ; probably a more nervous creature does not exist. If surprised suddenly, or brought to bay at close quarters, it may be too terror-stricken to attempt flight; then it bites, following a curious general rule which seems to obtain throughout nearly the whole animal world, from a passionate child downward, no matter what the natural weapons of offence may be. Young Felida will keep their talons sheathed until they have exerted all possible force with their soft milk-teeth, and a lizard will seize the hand which restrains it with its insignificant little jaws, when its tail or claws might inflict far more injury. The Boidce never use their constrictive powers in self-defence (unless they are gripped), and it seems probable that if a venomous snake's fangs lay in its tail, it would use its teeth first when attacked before bringing them into play. Indeed it must be remembered that very few animals are provided with exclusively defensive weapons, and that the python's enormous strength in constriction, the viper's poison apparatus, the lion's teeth and claws, and the electric discharge of the gymnotus are given them primarily for the purpose of securing their food.

A snake runs away, walking along on the points of its numerous ribs with a rapidity which can only be appreciated by those who have seen a long one-Herpetodryas, for instanceescaping in the open or over the bushes when alarmed, its speed being further increased by the body being drawn up at intervals into folds, which, being extended, shoot the head forward. This is the swiftest mode of progression of which a snake is capable, and is, as I have said, difficult to be realised from the spectacle of these reptiles in cages; the Brazilian neck-marked snake (Geopytas collaris), at the Zoological Gardens, will perhaps con- 
vey some idea of it, being certainly the most agile denizen of the Reptile House. But this movement is only an increase of the same action which is observed in one creeping slowly along, dis. played to best advantage when it is gliding from a plane to a raised surface. When a snake is in imminent danger, however, it adopts a remarkable motion for the purpose of eluding injury or capture, which motion, though it may be termed, par excellence, "serfentine," has, singularly enough, been very little commented upon by ophiologists.

The body is thrown laterally into a series of deep curves, which alternate so quickly from convexity to concavity that it is extremely difficult to touch or aim a blow with precision at any part of it, the lateral movements covering a square of ground, the side of which would be represented by at least two thirds of the snake's length. This motion is clearly protective in its object, and is only exhibited when the straight-onward movement is felt to be insufficient to avoid peril, since the reptile's speed in travelling is greatly retarded by it-necessarily so, as the head turns alternately from side to side at an angle of fully a hundred and twenty degrees to the line of its course, thus describing the major part of the circumference of a series of circles which the body and tail follow. Even a small one on a table will not be picked up without two or three ineffectual efforts, when it wriggles in this way, and I have seen a tiny Oxyrrhopus doliatus defend itself so for some moments against the lightning "dabs" of a serpentivorous bird; while a lively whip-snake, which was cruelly thrown to a peccary in my presence, actually twined away among the hog's feet and escaped into the jungle, in spite of the hungry and active animal's attempts to secure it. I was walking in the Botanical Gardens of Kio de Janeiro some time ago, when a lady called my attention to something going away among the ferns. Not being able to see it from where I stood, I jumped down the bank and found myself literally upon an immense green tree-snake, at least nine or ten feet long ; I was almost treading on it, but notwithstanding my mo:t energetic efforts to catch such a nagnificent specimen with my hands, feet, and the crooked handle of an umbrella, it succeeded in crossing an open space two yards wide, and disappeared into a clump of bamboo, solely by virtue of this lateral movement. I noticed that the intensity of the curvatures caused the ventral plates to be exposed, so that the yellowi.h under-colour was visible at each contortion; owing, no doubt, to the interlocking of the vertebrx, and consequent expenditure of the excess action in rolling.

This serpent, of course, was harmless, so that there would have been no danger in grasping it; but it emitted a curjous sound in its terror, such as I have never heard before or since. It screamed, and so loudly, that some people near, who saw nothing of what was going on, thought they heard a child cry. A snake's hissing, the only vocal expression of which the Ophidia are naturally capable, is produced simply by the rush of air through the narrow chink by which the trachea communicates with the pharynx, without any complex vibratory apparatus such as exists in mammals, though this may be prolonged for a considerable time on account of the enormous capacity of its single lung. I infer, therefore, that this one had just swallowed something, and that either its windpipe was not properly retracted to its normal position, or that the glottis was partially occluded by a pellet of mucus or (more probably) a filament of some extraneous material, which thus converted the hiss into a sort of whistle-just as boys produce a hideous screech by blowing forcibly on a blade of grass held edgewise between the applied knuckles of their two thumbs. Serpents make all sorts of noises besides hissing, according to their different kinds; Crotali spring their rattles; the carpet-viper (Echis carinata) rubs the imbricated scales of its adjacent coils together; the fer-de-lance (Trigonocephalus lanceolatus) is said in St. Lucia to give out a series of little taps with its horny extremity; and many others--such as the rat-snake (Spilotes variabilis) of South America-certainly indicate their presence when angry by quivering their tails against the ground; but a crying snake would have been a decided novelty in one's collection.

ArTHur Stradling

\section{UNIVERSITY AND EDUCATIONAL} INTELLIGENCE

UXFORD. - The date of the commencement of the examination for the Burdett-Coutts Scholarship has been postponed from Monday, Februarv 27, as announced, to Monday, March 6.

\section{SCIENTIFIC SERIALS}

The Quarterly Fournal of Microscopical Science for January, I882, contains: H. Marshall Ward, B.A., report on the morphology of the fungus of the coffee disease of Ceylon (Hemileia vastatrix, Brk. and Br.), plates $\mathrm{I}, 2$, and 3. This fungus probably belongs to the Uredines; still some structures, such as the curious spore-bearing head and the long-necked haustoria are opfosed to this alliance. The history of the adult fungus from the uredospore, and the formation of the teleutospores, are described and figured.-Dr. F. M. Balfour, on the nature of the organ in adult Teleosteans and Ganoids, which is usually regarded as the head-kidney or pronephros. It would seem probable that, though found in the larvæ or embryos of almost all the Icthyopsida, except the Elasmobranchii, this is always a purely larval organ, which never constitutes an active part of the excretory system in the adult forms -Dr. K. Mitsul uri (Japan), on the development of the supra-renal bodies in mammalia (plate 4). - Pat. Geddes, observations on the resting stage of Chlamydomyxa labyrinthuloides, Archer (plate 5), some very characteristic figures of the resting stage of this strange protean form are given.J. T. Cunningbam, a review of recent researches on Karyokinesis and cell division (plate 6). - Dr. Reuben T. Harvey, a note on the organ of Jacobson.--Prof. E. Ray Lankester, on Drepanidium ranarum, the cell-parasite of the frog's blood and spleen (Gaule's Würmschen). This very interesting memoir is illustrated with several woodcut illustrations.-G. F. Dowdeswell, M.A., on the micro-organisms which occur in Septicæmia (plate 7).-Prof. Bayley Balfour, Pringsheim's researches on chlcrophyll, translated and condensed (plates 8 and 9).

Fournal of Anatomy and Physiology for January, 1882, contains :-J. G. Smith, M.A., observations on the histology of fracture-repair in man (plates vi. and vii.); Dr. H. S. Gabbett, colloid degeneration of the non-cystic ovary with ascociated vascular changes (plate viii.); Dr. G. E. Dobson, the phalanx missing from certain digits in the manus of Chiroptera ; Dr. G. Thin, the histology of Molluscum contagiosum ; Dr. W. Osler, case of obliteration of the portal vein; Dr. A. H. Young, on the muscular anatomy of the Koala (Phascolarctos cinereus), with notes; Dr. M. Hay, on the action of saline cathartics; Dr. J. J. Charles, some researches on the gases of the bile.-Anatomical notices.

The Fournal of Physiology, vol. iii., Nos. 3 and 4, January, 1882.-Contents: H. N. Martin and W. T. Sedgwick, observations on the mean pressure and the characters of the pulsewave in the coronary arteries of the heart (plates 8-10).-H. Sewall, on the polar effects upon nerves of weak induction cur. rents.-E. A. Schäfer, on the temperature of heat-coagulation of certain of the proteid substances of the blood. $-F$. W. Mott and V. Horsley, on the existence of bacteria or their antecedents in healthy tissues (plate $\mathbf{~ I}$ ). - S. Ringer, the action of hydrate of soda, hydrate of ammonia, and hydrate of potash on the ventricle of the frog's heart (plates 12-13).-C. S. Roy, the physiology and pathology of the spleen (plates 14-16).-W. R. Gowers, loss of taste from disease of the fifth nerve - $H$. P. Bowditch and W. F. Southard, a comparison of sight and touch (plate 17).- J. N. Langley, on the destruction of ferments in the alimentary canal.-On the histology of the mammalian gastric glands and the relation of pepsin to the granules of the chief cells.-E. A. Schäfer, simple method of demonstrating the alkaloid reaction of the blood. - C. E. Webster, note on the production of the heart-sound.

Morphologisches Fahrbuch. Eine Zeitschr ift für Anatomie und Entwickelungsgeschichte, vol. vii. part 3, I88I, contains-Dr. Hans Gadow, a contribution to the myology of the posterior extremities of the reptiles (plates 17-2I).-Dr. G, von Koch, on the anatomy of Clavularia prolifera, sp.n., with notes on the buds in some Alcyonaria; on C. ochracea; on the connection of the buds with the stem in the colony of C. prolifera; and on the relationship of the spicules to the ectoderm (plates 22 and 23). -Dr. J. E. V, Boas, on the conus arteriosus and the arch of the aorta in the amphibians (plates 24 to 26).

Niederländisches Archiv für Zoologie.-Supplement Band i. Part 2 (Leiden, 1881), contains the first half of a very valuable paper by Dr. R. Horst, of Utrecht, on the Gephyrea collected during the first two voyages of the Willem Barents. $\rightarrow$ On Hamingia glacialis, n.sp., plate $i$, and a memoir on Proneomenia sluiteri, gen. et. sp. nov., with remarks upon the anatomy and histology of the Amphineura, by Dr. A. A. W. Hubrecht, 